\title{
Dwudziestopięcioletnia chora z anoreksją i podejrzeniem ostrego zespołu wieńcowego*
}

\section{5-year-old patient with anorexia and suspected acute coronary syndrome}

\author{
Michał Bączek ${ }^{1,2}$, Iwona Gorczyca ${ }^{1}$, Katarzyna Starzyk ${ }^{1}$, Beata Wożakowska-Kapłon ${ }^{1,2}$ \\ ${ }^{1}$ I Klinika Kardiologii i Elektroterapii Świętokrzyskiego Centrum Kardiologii w Kielcach \\ ${ }^{2}$ Wydział Lekarski i Nauk o Zdrowiu Uniwersytetu Jana Kochanowskiego w Kielcach
}

\section{Streszczenie}

Opisano przypadek 25-letniej chorej z jadłowstrętem psychicznym przyjętej do kliniki kardiologii z powodu podejrzenia ostrego zespołu wieńcowego. Na podstawie prezentowanego przypadku autorzy zwracają uwagę na skalę powikłań narządowych anoreksji oraz sposób prowadzenia odpowiedniego leczenia żywieniowego.

Słowa kluczowe: anoreksja, powikłania kardiologiczne

Folia Cardiologica 2017; 12, 6: 601-603

\section{Wstęp}

Jadłowstręt psychiczny jest zaburzeniem odżywiania prowadzącym do istotnego ograniczenia ilości spożywanego pokarmu. Dane z badań epidemiologicznych ukazuja wyraźny wzrost liczby zachorowań, czyniąc jadłowstręt psychiczny trzecią pod względem częstości występowania przewlekłą chorobą u dorastających dziewcząt. Zaburzenia odżywiania powodują liczne zaburzenia funkcjonowania organizmu, ze zmianami somatycznymi, metabolicznymi i endokrynologicznymi włącznie. Powikłania ze strony układu sercowo-naczyniowego stanowią drugą, po samobójstwach, przyczynę nagłych zgonów [1].

\section{Opis przypadku}

Chora w wieku 25 lat, od 2 lat leczona z powodu jadłowstrętu psychicznego, trafiła do kliniki kardiologii z oddziału wewnętrznego szpitala powiatowego z powodu podejrzenia zawału serca z uniesieniem odcinka ST (STEMI, ST-elevation myocardial infarction). W chwili przyjęcia była przytomna, nie zgłaszała dolegliwości bólowych w klatce piersiowej. Masa ciała chorej wynosiła $32 \mathrm{~kg}$, natomiast wskaźnik masy ciała (BMI, body mass index) $-11 \mathrm{~kg} / \mathrm{m}^{2}$. W badaniu elektrokardiograficznym (EKG) wykonanym przy przyjęciu uwidoczniono uniesienie odcinka ST w odprowadzeniach kończynowych I, aVL oraz przedsercowych V2-V3 (ryc. 1).

W badaniach laboratoryjnych stwierdzono niedokrwistość, małopłytkowość, hipoalbuminemię, podwyższone do $1392 \mathrm{pg} / \mathrm{ml}$ wartości peptydu natriuretycznego typu B (BNP, B-type natriuretic peptide), kinazy fosfokreatynowej (CPK, creatine phosphokinase) do 1071 j/l, frakcji sercowej kinazy kreatynowej (CK-MB, creatine kinase myocardial bound) do 46 j./I oraz troponiny T mierzonej metodą wysokoczułą do 63,2 ng/l. W kolejnej próbce nie wykazano dynamicznego wzrostu markerów martwicy mięśnia sercowego. U chorej nie stwierdzono klasycznych czynników ryzyka sercowo-naczyniowego. Stężenie cholesterolu frakcji LDL (low-density lipoprotein) wynosiło $16 \mathrm{mg} / \mathrm{dl}$. W przezklatkowym badaniu echokardiograficznym uwidoczniono scieńczały mięsień sercowy z uogólnioną hipokinezą ścian lewej komory, frakcja wyrzutowa lewej komory wynosiła 44\%, jamy serca nie były poszerzone (ryc. 2).

*Praca powstała w ramach realizacji projektu: „Zakup wyposażenia I Klinicznego Oddziału Kardiologii i Pracowni Elektrofizjologii szansą na zwiększenie innowacyjności Wojewódzkiego Szpitala Zespolonego w Kielcach" współfinansowanego przez Unię Europejską ze środków Europejskiego Funduszu Rozwoju Regionalnego w ramach Regionalnego Programu Operacyjnego Województwa Świętokrzyskiego na lata $2007-2013$

Adres do korespondencji: lek. Michał Marian Bączek, I Klinika Kardiologii i Elektroterapii, Świętokrzyskie Centrum Kardiologii, ul. Grunwaldzka 45, 25-736 Kielce, e-mail: michalo.baczek@gmail.com 


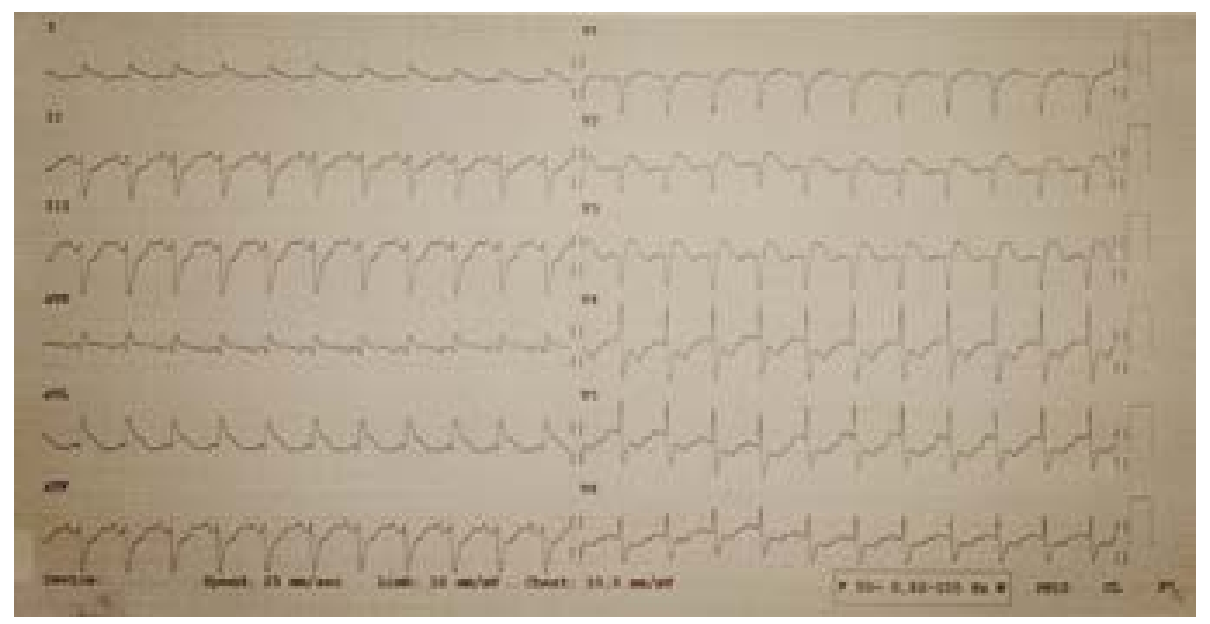

Rycina 1. Badanie elektrokardiograficzne wykonane przy przyjęciu - uniesienie odcinka ST w odprowadzeniach I, avL oraz V2-V3

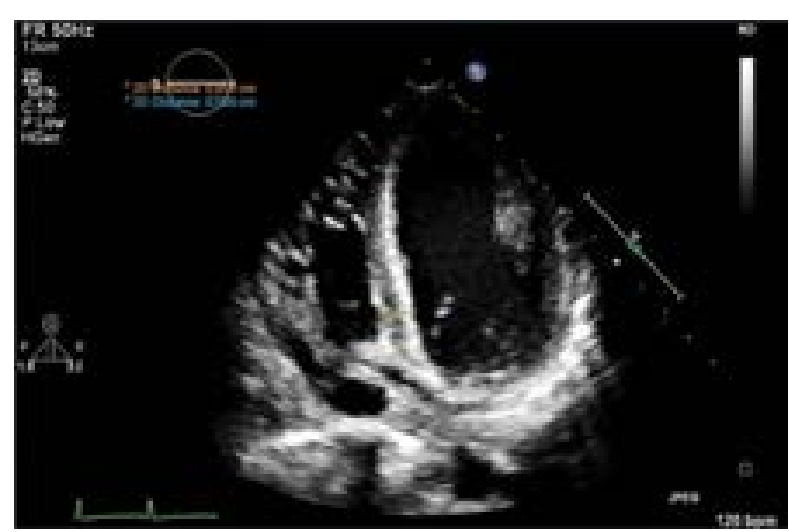

Rycina 2. Scieńczały mięsień sercowy lewej komory w projekcji koniuszkowej czterojamowej

U chorej rozpoznano uszkodzenie mięśnia sercowego w przebiegu kacheksji oraz włączono leczenie farmakologiczne niewydolności serca - bisoprololem w dawce 2,5 mg oraz lisinoprilem w dawce $5 \mathrm{mg}$. W trakcie hospitalizacji stan pozostawał stabilny. Rozpoczęto leczenie realimentacyjne, stopniowo zwiększając liczbę spożywanych przez pacjentki kalorii, uzyskując przyrost masy ciała $1 \mathrm{~kg}$ w ciągu tygodnia. Chorą konsultowano psychiatrycznie; dołączono lek przeciwdepresyjny z grupy inhibitorów wychwytu zwrotnego serotoniny, a następnie przekazano na oddział psychiatrii w celu dalszego leczenia zaburzeń odżywiania. Chora pozostaje pod stałą opieką poradni kardiologicznej.

\section{Omówienie}

Przewlekłe głodzenie u chorych z jadłowstrętem psychicznym prowadzi do wystąpienia wielu poważnych powikłań kardiologicznych stanowiących zagrożenie dla życia. Zmiany w badaniu EKG obserwuje się u ponad $80 \%$ badanych. Można stwierdzić takie nieprawidłowości, jak: bradykardia lub tachykardia zatokowa, zaburzenia przewodnictwa, komorowe i nadkomo- rowe zburzenia rytmu serca, wydłużenie odcinka QT, zmiany odcinka ST o typie zarówno obniżenia, jak i uniesienia odcinka ST [2-5]. Wywiad (młody wiek, brak dolegliwości bólowych w klatce piersiowej, niskie ryzyko zmian miażdżycowych), badanie przedmiotowe oraz wyniki badań laboratoryjnych pozwoliły na wykluczenie ostrego zespołu wieńcowego, natomiast rozpoznano uszkodzenie mięśnia lewej komory na tle niedoborów żywieniowych. W badaniu Mont i wsp. [6] wykazano, że niekorzystne zmiany w układzie sercowo-naczyniowym, takie jak zmniejszenie objętości wyrzutowej, obniżenie tolerancji wysiłku czy scieńczenie ściany lewej komory serca, są odwracalne dzięki zastosowaniu odpowiedniego leczenia zaburzeń odżywiania. Nie zaleca się prowadzenia zbyt szybkiej realimentacji, gdyż może ona doprowadzić do groźnych dla życia i zdrowia powikłań, między innymi hipofosfatemii, zaburzeń rytmu serca, niewydolności krążenia, niewydolności oddechowej, anemii hemolitycznej, niewydolności nerek, a nawet zgonu. Zespół tych powikłań określa się mianem zespołu realimentacyjnego (refeeding syndrome). Zwiększenie objętości krwi krążącej może spowodować nadmierne obciążenie uszkodzonego mięśnia sercowego, prowadząc do rozwinięcia się pełnoobjawowej niewydolności serca. Zaleca się, aby przyrost masy ciała u hospitalizowanych chorych wynosił 0,5-1,0 kg w ciągu tygodnia. Na początku leczenia stosuje się dietę o wartości około $500 \mathrm{kcal}$ (40-50 kcal/ /kg mc.), następnie stopniowo zwiększa się jednorazowe ilości energii w posiłku o nie więcej niż $200 \mathrm{kcal}$ (60-80 kcal/ /kg mc.), aż do uzyskania 2000-3000 kcal/dobę [7, 8].

\section{Podsumowanie}

Jadłowstręt psychiczny jest związany z poważnymi zaburzeniami układu sercowo-naczyniowego pogarszającymi rokowanie. Diagnostyka i leczenie powikłań u tych chorych wymagają interdyscyplinarnego postępowania. Implementacja odpowiedniego leczenia żywieniowego w większości przypadków prowadzi do powrotu prawidłowej funkcji narządów. 


\section{Abstract}

We present the case of a 25-year-old woman, suffering from anorexia nervosa, admitted to the Department of Cardiology on suspicion of acute coronary syndrome. Based on the case, the authors point out severity of organ damage and how to perform proper nutrition treatment.

Key words: anorexia, cardiological complications

Folia Cardiologica 2017; 12, 6: 601-603

\section{Piśmiennictwo}

1. Isner JM, Roberts WC, Heymsfield SB, et al. Anorexia nervosa and sudden death. Ann Intern Med. 1985; 102(1): 49-52, indexed in Pubmed: 3966745.

2. Bartkowiak R, Wożakowska-Kapłon $B$, Janion $M$, et al. Zmiany w układzie krążenia u chorych $\mathrm{z}$ jadłowstrętem psychicznym. Forum Kardiologów. 2005; 10: 39-42.

3. Cooke RA, Chambers JB. Anorexia nervosa and the heart. Br J Hosp Med. 1995; 54(7): 313-317, indexed in Pubmed: 8556209.

4. Palla B, Litt IF. Medical complications of eating disorders in adolescents. Pediatrics. 1988; 81(5): 613-623, indexed in Pubmed: 3162764.
5. Sharp CW, Freeman CP. The medical complications of anorexia nervosa. Br J Psychiatry. 1993; 162: 452-462, indexed in Pubmed: 8481735.

6. Mont L, Castro J, Herreros B, et al. Reversibility of cardiac abnormalities in adolescents with anorexia nervosa after weight recovery. J Am Acad Child Adolesc Psychiatry. 2003; 42(7): 808-813, doi: 10.1097/01. CHI.0000046867.56865.EB, indexed in Pubmed: 12819440.

7. Rajewski A. Zaburzenia odżywiania się. Psychiatria Przew Lek. 2003; 6(3): 110-115.

8. Kaplan HI, Sadock BJ, Sadock VA. Psychiatria kliniczna. Wydawnictwo Elsevier Urban \& Partner, Wrocław 2004. 